\title{
Patterns of turbulence and stability: Towards a dynamic sociotechnical model of technological change
}

\author{
D.A.L. Coldwell \\ Chamber of Mines Research Organization, Human Resources Laboratory
}

A major problem in the introduction of technological change is that a basically beneficial technology can be rejected, or rendered less effective, because workers perceive it as being counter to their interests. This article outlines the fluctuation in workers' attitudes towards the introduction of a technological innovation on a gold mine. Utilizing data obtained from three separate investigations conducted over a two-year period, a tentative, empirically based, dynamic model of technological change is generated. The model suggests that certain pre-emptive steps can be taken by management to maximize the chances of success in the implementation of technical innovations.

S. Afr. J. Bus. Mgmt. 1985, 16: $31-34$

By die invoering van tegnologiese verandering is ' $n$ wesenlike probleem dat ' $n$ tegnologie wat fundamenteel voordelig is, verwerp kan word, of minder doeltreffend kan funksioneer, omdat werknemers dit as teenstrydiy met hulle belange sien. Hierdie artikel skets die wisseling in die houdings van werknemers ten opsigte van die invoering van 'n tegnologiese verandering op 'n goudmyn. Deur gebruik te maak van gegewens wat ingewin is gedurende drie afsonderlike ondersoeke, uitgevoer oor 'n tydperk van twee jaar, is 'n voorlopige, empiriesgefundeerde, dinamiese model vir tegnologiese verandering ontwikkel. Die model doen aan die hand dat sekere voorkomende stappe deur bestuur gedoen kan word om maksimale kanse vir die suksesvolle implementering van tegnologiese veranderings te verseker. S.Afr. Tydskr. Bedryfsl. 1985, 16: $31-34$

\section{D.A.L. Coldwell}

Chamber of Mines Research Organization, Human Resources

Laboratory, Box 91230, Auckland Park,

2006 Republic of South Africa

\section{Introduction}

Sociotechnical models tend to emphasize the social reaction to technical change without considering the repercussions of the social on the technical, yet the sociotechnical model is purportedly concerned with the reciprocal action of the one upon the other (albeit with technology usually as the senior partner). As Pasmore, Francis \& Haldeman (1982) put it: 'Given that technological changes are reported in relatively few sociotechnical system experiments, we must conclude that much of the long-heralded success of sociotechnical interventions may have more to do with changes in the social system and the qualifications of personnel than with the joint optimization of social and technical systems'. Moreover they note that ' $\ldots$ relatively few sociotechnical experiments actually involve technological changes: instead, most concentrate on rearranging the social system around an existing technology in order to approximate joint optimization' (p.1185). In other words, the traditional sociotechnical approach has tended to focus on how a technology $X$ can be optimized by rearrangements in a social system $Y$, and has tended to neglect the equally important question of how technology $X$ could be modified to meet the demands of social system $Y$. I use 'social system' here in the widest possible sense to mean both the more specifically psychological reactions to technological change, in addition to the purely sociological aspects which concern the effects of change on social interaction. The sociotechnical approach can either be more sociological, by emphasizing the effects of technology on work-group organization and interaction, or more psychological, by focusing on attitudinal reactions to technological change (Davis \& Taylor, 1976:379-413). Similarly, the approach can either be micro-oriented, by attending to a particular technological change within an organization which otherwise remains the same; or macro-oriented by investigating the effects of a complete change in the technological basis of an industry (as, for example, in the change from a basically unautomated to a highly automated production plant) (Thorsrud, Sorensen \& Gustavsen, 1976: 421-464).

This article is concerned with attitudinal reactions to a specific technological change on one mine, it thus adopts a more psychological and micro-orientation. However, attitudes are never generated in a vacuum, but are built up through social interaction. Thus, rumour, hearsay, and halo building for workers not directly involved in the operation of a new technology, yet who have an important influence on its ultimate success or failure, obtain their knowledge of it, and build attitudes towards it, through social interaction. Similarly, those directly involved in the operation of the new technology 
evolve attitudes towards it through individual and social experiences with it. Although certain individual differences may remain, consensus as to whether the technology is advantageous, disadvantageous, or threatens workers' interests is usually reached after a period of time. It is argued that such consensus of opinion is built up through mutual interaction and reinforcement and is dynamic rather than static. Specifically, it is maintained that attitudes towards a new technology are turbulent initially but later become more stable as the technology becomes better known and understood and a final general consensus of opinion emerges. However, before going on to describe the model in detail it is necessary to outline the technological change to which it refers, the context in which it evolved, and the method and techniques used in its composition. This is the purpose of the following two sections.

\section{Background to the investigation}

The investigation was conducted on a South African gold mine and focussed on the attitudinal reactions of Black workers towards the introduction of a small hydraulic rockdrill for hand-held use capable of drilling appreciably more holes in a shift than the existing pneumatic drills. The Chamber of Mines' Newsletter (1984:1 - 4) reports: 'A rockdrill incorporating completely new engineering technology and with the potential to significantly improve productivity in South Africa's gold mines has been developed by the Research Organisation of the Chamber of Mines in collaboration with a major engineering company. A full production trial of the new hydraulic drill completed in March this year has shown it to have the following advantages over pneumatic drills currently in use:

- It is considerably more efficient, drilling an average of more than 55 holes per drilling crew per shift compared with the industry average for crews using pneumatic drills of about 30 holes.

- It is much quieter - resulting in a high level of user acceptance.

- Better visibility at the rockface as the hydraulic drill does not produce the fog associated with the use of compressed air.

- More efficient energy use.

In view of the encouraging results obtained at the trials, it is hoped that the new drill will gain quick acceptance with the mining industry' (p.2).

The Newsletter also narrates how certain technical problems were resolved during the trials, in particular how new hoses and hose fittings were developed to improve their durability and thus the reliability of the drill. The importance of these initial 'teething problems', and their subsequent eradication, on workers attitudes towards the new technology will become apparent later in the article.

\section{Method}

Samples consisting of Black workers including supervisors, drill operatives and manual workers were selected for three separate investigations ( $n=40,87$, and 50 workers respectively) conducted at different times over a two-year period. The samples included workers directly and indirectly involved with the new drill. Changes in attitudes were monitored over the two-year period by means of a questionnaire designed to elicit workers' views regarding the benefits and drawbacks of the hydraulic drill compared with the pneumatic drill. In particular, aspects of performance/reliability and safety/ease of operation were emphasized.

\section{Outline of the findings and the development of the model}

Without going into specific details, the empirical evidence obtained through the three investigations conducted at different points in time during the trials seemed to suggest that three basic stages were discernible in the attitudinal reactions to the introduction of the hydraulic drill.

The first stage, which corresponded to the initial engineering trials and the first attitude study, was characterized by generally favourable attitudes towards the hydraulic drill. Deficiencies, particularly regarding reliability, had not yet become fully apparent owing to the newness of the equipment. Thus, while benefits such as the improved speed and quietness of the new hydraulic drill compared to the pneumatic drill tended to be emphasized by the workers, its shortcomings were overlooked, or had not yet had time to emerge.

In the second stage, which corresponded to the early production trials and the second empirical investigation, the hydraulic drill entered a difficult 'teething' period characterized by breakdowns and poor reliability. During this stage scepticism developed and workers' attitudes became increasingly unfavourable towards the drill, particularly concerning its safety and handling characteristics.

The third stage corresponded to the later production trials and the third investigation. The number of breakdowns had been substantially reduced by this stage and certain other outstanding problems had been solved. This resulted in more favourable attitudes among workers towards the drill, evidenced particularly in their enhanced perception of its safety. The safety of the drill was, of course, directly linked to its reliability, and with the enhanced reliability of the drill, workers could be expected to regard it as safer. However, certain other aspects of the hydraulic drill, which had already been recognized by workers as safety features in the initial attitude study (such as reduced noise) were reiterated in the third investigation suggesting that the increased reliability of the drill had brought about a re-assessment and re-emphasis by workers of the drill.

The evidence suggests that while attitudes react to real changes in the machine, particularly its reliability, they often react more strongly and with greater volatility than would be expected. In other words, a halo-effect is created whereby the attitudes of workers towards certain not-purely-technical features, such as safety, fluctuate considerably over time. Thus, in this specific instance, the attitudes of workers towards safety can be regarded as a barometer of social psychological reactions to technological change.

This empirically supported monocyclical change process can best be illustrated by means of a diagram.

Figure 1 presents a tentative five-step, six-stage sociotechnical model of the technological change process.

Figure 1 indicates that the six stages of change are divided into three distinct social-psychological stages (Stages 1, 4 and 6) and three distinct technological stages (Stages 2, 3 and 5). It is important to note that, apart from the first stage where workers have had no prior contact with the machine, attitudes always react to technological changes and not the other way round. Thus, the steps indicated in the diagram are chronological: Step 1 comes before Step 2, Step 2 before Step 3, and so on.

The social psychological stages, like the technological stages, are divided into two main clusters corresponding to periods of turbulence and stabilization in attitudes and technology respectively. Thus Stages 1, 2, 3, and 4 are stages of attitudinal/technological turbulence (denoted as $A_{1}$ and $B_{1}$ in 

Stages of Attitudinal Turbulence

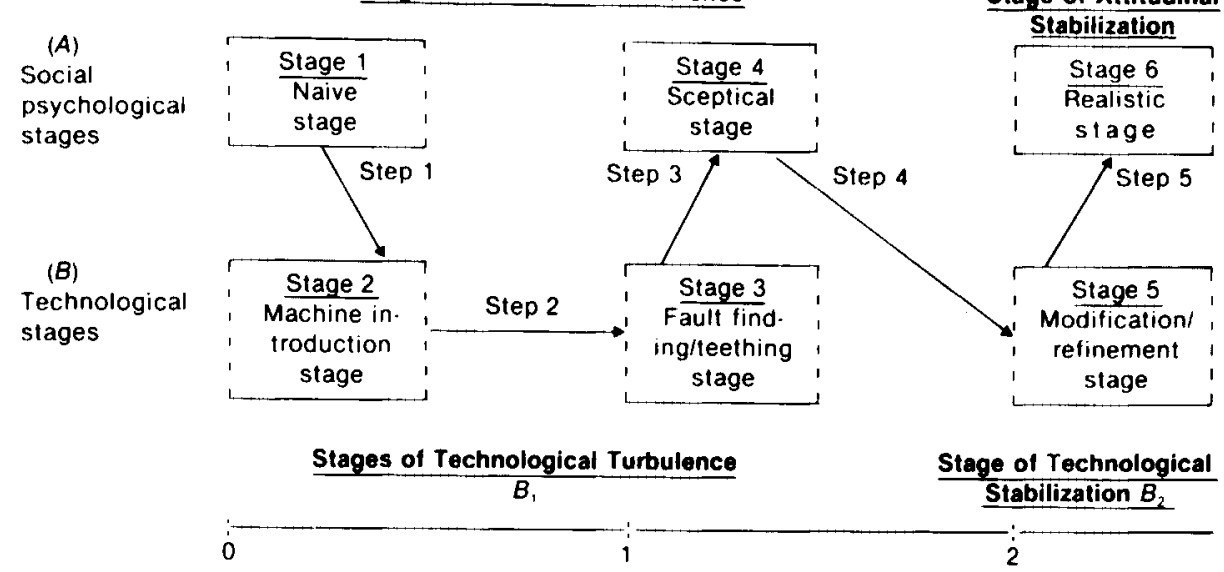

Figure 1 A tentative five-step, six-stage sociotechnical model of technological change

the diagram) while Stages 5 and 6 are stages of attitudinal/ technological stabilization (indicated as $A_{2}$ and $B_{2}$ in the diagram). (The specific meaning of these terms will become apparent later in the more detailed discussion of the individual stages.)

The time scale in Figure 1 is calibrated $0,1,2$. Roughly speaking, the period $0-1$ corresponds to the engineering trial phase, $1-2$ to the early production trial phase, and 2 and beyond to the late production phase. Having given an outline description of the model it is now possible to define each of the individual stages in more detail.

Assuming no introduction of change programme is implemented before the introduction of the technology, the naive stage (Stage 1) is characterized by attitudinal neutrality or tentatively positive feelings towards the new technology. The workers have not actually used the technology before and, given the initial assumption, approach it naively.

Stage 2 corresponds to the machine introduction stage. This stage is characterized by the newness of the machinery which hides faults which emerge later.

Stage 3 corresponds to the fault finding/'teething' stage which is characterized by the emergence of faults whose gradual appearance through prolonged use creates a reliability problem.

Stage 4 , the sceptical stage, is characterized by workers questioning the benefits of the new technology and involves an erosion of favourable attitudes in reaction to the appearance of faults in the machinery and the concomitant falling off of reliability.

Stages $1-4$ are regarded as turbulent stages as pronounced changes in attitudes, largely in response to changes in machine reliability, are experienced.

Stage 5 corresponds to the technological modifications and refinement stage and is characterized by the increasing reliability of the machine as faults are solved and problems ironed out.

Finally, Stage 6, the realistic stage, is in the case of the hydraulic drilling system at least, characterized by attitudes becoming more favourable in response to the increasing reliability of the technology and realistic appraisals of the technology's true potential becomes possible. Of course it is perfectly possible that the realistic stage could be characterized by attitudes remaining or becoming more unfavourable ultimately leading to the rejection of the technology. If, for example, workers begin to feel that the technology is counter to their interests, the result could be a complete rejection of it. Nor does such a scenario require much imagination to visualize; the history of technical change is full of examples of outright rejection, or costly implementation because of unwarranted fears or unrealistic expectations of the workers (Parker, Brown, Child \& Smith, 1972:116).

Stages 5 and 6 are regarded as the stages of stabilization, both in terms of workers' attitudes and the reliability of the machine. In no way is this intended to suggest that further fluctuations in attitudes and reliability do not occur as, clearly, such fluctuations are possible. However, they are likely to be minor relative to the turbulent stages and, in time, to lead to further stabilization.

\section{Some practical implications of the model}

It would be wrong to make grandiose generalizations from one particular case study and this is not attempted. The model can only be regarded as tentative and considerable further empirical testing will be required before it can be generally accepted. However, assuming further empirical testing generally supports the model's validity, it can provide management, faced with the problem of implementing a specific technological innovation, with certain practical guidelines. The key utility of the model is seen as residing in its description of the empirical process of technological change. The overriding practical implication of the model is that management should aim to minimize the erosion of favourable attitudes in response to reliability problems experienced during the 'teething' stage of the technology's introduction. By doing so management will stand a better chance of introducing the technology smoothly into the existing organization.

How can management accomplish this and when should they attempt to do so?

The model suggests that the most favourable times for managerial intervention are before the introduction of the technology and during the initial engineering and early production trials. How? Suggestions as to how management might accomplish this can be listed as follows:

- Drawing up an introduction of change programme before the initial engineering trial outlining the advantages and possible pitfalls of the new technology in a realistic, matterof-fact manner;

- modifying and updating the introduction of change programme with information obtained in attitude-type surveys conducted during the introductory stages; 
- encouraging workers to make suggestions for improving the technology by eliciting their opinions and by setting up quality control type groups;

- providing feedback on the action taken by management to curb particular problems and informing workers of the ways their suggestions have been applied in specific instances; and

- providing on- and off-the-job training courses with a view to upgrading workers' skills and boosting their morale by engendering a greater commitment to and interest in the new technology.

The importance of managerial strategy in introducing change cannot be over-stressed as Parker, et al. (1972) clearly point out: 'The way in which changes are introduced is [also] important; conditions of secrecy, with no information until a late stage are likely to give rise to greater anxiety and resistance to change than are cases where information is given, or even more so where those involved participate in planning the changes'.

\section{Conclusion}

A dangerous non sequitur posed by the adoption of the sociotechnical approach is to assume that, because technology influences the social system of an organization, the social system of an organization therefore is determined by its technology. Managerial choices and preferences play a large part in the social organization of a firm and their decisions may not always reflect the optimization of a social system in terms of a given technology. Similarly, workers' motivations and expectations of work; in short, their prior orientations to work, may profoundly influence their perceptions of the technology.

I think most observers would agree that many unskilled and semi-skilled Black workers do not expect their jobs to be intrinsically satisfying, but regard them largely as a means of earning a living. Thus, their expectations from work are relatively basic and usually focus on safety, pay, employment security, and the physical arduousness of the job. It follows that any new technology which can adversely, or beneficially, affect any one of these different aspects is likely to be assessed carefully by workers directly involved in using it and those indirectly associated with it.

Finally, a sociotechnical system must have economic viability. As Rose (1978:215) puts it: ' . . . the productive system has three key dimensions which are interdependent: the technological, the social and the economic. Yet each of these posesses its own scale of independent values. To pursue one set of values and ignore the others is to invite trouble, if not disaster; more formally, optimizing along one dimension does not produce optimal results for the system as a whole. Overall system optimization usually implies sub-optimizating along each dimension'.

What this article has tried to convey is that technological change must be carefully introduced into an organization to minimize the possibility of a hostile reaction from workers. If, it is argued, a technical innovation is introduced in a carefully pre-planned way, paying special attention to social psychological aspects such as workers' attitudes towards the technology, and encouraging their suggestions for remedial action, the project stands a much greater chance of success. The model, by identifying the various sociotechnical stages of technological change, gives management the necessary framework for accomplishing this task.

\section{References}

Davis, L.E. and Taylor, J.C. 1976. Technology, Organization and Job Structure in Dubin, R. (Ed) Handbook of Work, Organization and Society. Chicago: Rand McNally, pp. $379-413$.

Chamber of Mines' Newsletter; 1984 April/May, pp.1 - 4.

Parker, S.K., Brown, R.K., Child, J. and Smith, M.A. (1972). The Sociology of Industry. London: Allen and Unwin, p. 116.

Pasmore, W., Francis, C. and Haldeman, J. (1982). Sociotechnical Systems: Reflections on Empirical Studies of the Seventies. Hum. Rel., 35, 1195.

Rose, M. (1978). Industrial Behaviour. Harmondsworth: Penguin, p.215.

Thorsrud, E., Sorensen, A. and Gustavsen, B. (1976). Sociotechnical Approach to Industrial Democracy in Norway in Dubin, R. (Ed) Handbook of Work, Organization and Society. Chicago: Rand McNally, pp.421-464. 